\title{
POLA KOMUNIKASI DALAM MEMPERTAHANKAN EKSISTENSI BUDAYA PESANTREN DI PULAU BANGKA
}

\author{
Yera Yulista \\ IAIN Syaikh Abdurrahman Siddik Bangka Belitung, Indonesia \\ yerayulista@iainsasbabel.ac.id
}

\begin{abstract}
Abstrak: Pesantren merupakan salah satu pilihan tempat untuk menimba ilmu Agama Islam. Di tengah persaingan yang semakin ketat ini pengelola pontren tentu memerlukan usaha agar pondok keberadaannya dapat terus bertahan. Untuk mempertahankan keberadaan pontren tersebut para pemilik pontren akan berusaha semaksimal mungkin mempertahankan hal tersebut, terlebih melihat kondisi sekarang semakin banyak bermunculan pontren baru yang memiliki ragam layanan pendidikan. Oleh sebab itu, para pengelola pesantren merasa perlu untuk mempertahankan nilai-nilai tersebut yakni mempertahankan budaya yang bisa jadi telah lama mengakar menjadi ciri khas identitas pontren sehingga keberadaannya tetap menjadi incaran para calon santri. Diantara cara yang dapat digunakan untuk mempertanhkan nilai tersebut adalah dengan mensosialisasikannya melalui aktivitas komunikasi. Komunikasi yang terus-menerus dilakukan dalam mentransfer nilai budaya pada akhirnya akan membentuk ciri khas pola komunikasi pontren sehingga pada akhirnya pola komunikasi memiliki peran penting dalam mempertahankan eksistensi budaya pontren khususnya pontren. Peneliti dalam hal ini akan meneliti pontren yang menjadi pionir berdiri di Pulau Bangka yang sampai saat ini masih tetap eksis walaupun ditengah mereka sudah bermunculan pontren yang lain.
\end{abstract}

Kata Kunci: Budaya, Pesantren, Pola Komunikasi 
Pola Komunikasi dalam Mempertahankan Eksistensi Budaya Pesantren di Pulau Bangka

\section{A. Pendahuluan}

Pembelajaran Banyak cara bagi para muslim yang ingin belajar untuk memperdalam Islam .Salah satu wadah untuk memperdalam Islam adalah dengan melibatkan diri didalam sebuah lingkungan pesantren, yakni tempat dimana ajaran Islam diajarkan dan diterapkan. Pesantren adalah suatu lingkungan pilihan tempat bagi mereka yang ingin menimba ilmu ataupun mengajarkan ilmu dunia ataup ilmu akhirat yang pada akhirnya tujuan dari hal tersebut hanyalah untuk mendapat kehidupan yang bahagia, berkah dunia akhirat.

Ketika berbicara pesantren tentunya mayoritas aktivitas kepesantrenan biasanya terpusat pada satu tempat (local). Tidaklah keliru jika menilai pesantren adalah sebuah sekolah tempat kegiatan proses belajar mengajar ilmu umum atau secara spesifik lebih banyak menimba beragam macam kelimuwan khususnya di bidang agama Islam karena fokus untuk memperdalam ilmu agama lebih banyak di pesantren dibandingkan lembaga lembaga pendidikan formal umumnya.

Pondok pesantren (pontren) adalah sebuah organisasi atau sistem yang memiliki aturan dan terdiri dari berbagai pihak yang berada dalam lingkungan pesantren tersebut diantaranya pemilik pesantren itu sendiri, pengurus, para pendidik atau yang lebih popoler dikenal dengan sebutan ustadz (guru laki-laki) dan ustadzah (guru wanita) dan para santri. Orang-orang yang memilih untuk bergabung dalam lingkungan pesantren tentunya harus siap untuk saling menyesuaikan diri baik dalam proses interaksi dengan berbagai karakter orang lain didalamnya maupun dengan keberagaman nilai yang menjadi budaya dalam lingkungan pesantren itu sendiri. Hal ini dikarenakan mayoritas mereka yang berkecimpung didalam pesantren akan menetap tinggal dalam lingkungan pesantren dalam waktu yang lama dan tentunya menuntut adanya penyesuaian dengan lingkungan.Kesemua elemen sub sistem ini harus saling bersinergi dalam menjalankan peran mereka masing-masing karena dengan berusaha menyelaraskan peran tersebut maka akan mudah mempertahakan eksistensi dari pesantren itu sendiri.

Untuk mempertahankan eksistensi dari pesantren tentunya ada berbagai macam aturan yang terikat baik aturan yang dibuat secara tertulis maupun tidak yang pada akhirnya menjadi budaya dalam lingkungan tersebut. Budaya-budaya di tiap pesantren tentunya tidak selalu samakan karena biasanya memiliki kekhasan tersendiri sehingga berbeda dengan pesantren lainnya. Kebudayaan menurut antropolog E.B. Taylor adalah kompleks yang 
mencakup pengetahuan, kepercayaan, kesenian, moral, hukum, adat istiadat dan lain kemampuan-kemampuan serta kebiasaan-kebiasaan yang didapatkan oleh manusia sebagai anggota masyarakat. ${ }^{1}$

Dari definisi yang dijabarkan diatas apabila dikaitkan dengan lingkungan pesantren maka jelas akan memiliki keberagaman budaya yang merupakan subbudaya untuk menguatkan keberadaan sistem pontren tersebut sehingga pesantren akan tetap bisa bertahan ditengah banyak nya persaingan antar pesantren. Menurut K.H. Abdurrahman Wahid menyebutkan terdapat tiga elemen yang mampu membentuk pondok pesantren sebagai subkultur yakni 1) pola kepemimpinan pondok pesantren yang mandiri tidak terkooptasi oleh negara 2) kitab-kitab rujukan umum yang selalu digunakan dari berbagai abad dan 3) sistem nilai (value system) yang digunakan adalah bagian dari masyarakat luas. ${ }^{2}$

Budaya akan tetap bertahan jika semua subsistem dalam pesantren saling berusaha untuk mempertahankan budaya tersebut yang dapat dilakukan melalui interaksi komunikasi yakni suatu aktivitas penyampaian pesan dari level paling tinggi hingga level komunikasi yang rendah, baik yang dilakukan pemilik, pimpinan pesantren, para pendidik ataupun para santri yang saling berinteraksi dalam keseharian mereka untuk dapat mempertahankan budaya pesantren tersebut. Komunikasi menurut Diana K. Ivy dan Phil Backlund adalah proses yang terus berlangsung dan dinamis menerima dan mengirim pesan dengan tujuan berbagi makna. ${ }^{3}$

Dari hal ini kita bisa menyimpulkan bahwa budaya dalam suatu lingkungan pesantren akan bertahan jika ada usaha untuk mempertahankan kebudayaan itu sendiri melalui komunikasi. Komunikasi adalah salah satu kunci untuk menjaga sebuah nilai budaya artinya adanya budaya tanpa dikomunikasikan maka keberadaan budaya tersebut akan terancam hilang, walaupun budaya itu hanyalah bermula dari hal-hal yang sederahana namun jika ingin tetap bertahan maka nilai-nilai tersebut harus dibicarakan, disosialisasikan walaupun melalui level komunikasi yang sederhana sekalipun. Dengan kata lain aktivitas komunikasi adalah aktivitas yang tidak dapat ditinggalkan dalam ranah mempertahankan budaya dalam pesantren itu sendiri. Budaya pesantren tentunya muncul dari pola-pola sikap dan perilaku

\footnotetext{
${ }^{1}$ Soerjono Soekanto dan Budi Sulistyowati, Sosiologi Suatu Pengantar Edisi Revisi (Jakarta: PT RajaGrafindo Persada), hlm. 148.

${ }^{2}$ Sa'id Aqiel Siradj dkk, Pesantren Masa Depan Wacana Pemberdayaan dan Transformasi Pesantren (Bandung: Pustaka Hidayah, 1999), hlm. 14.

${ }^{3}$ Deddy Mulyana, Ilmu Komunikasi Suatu Pengantar (Bandung: PT Remaja Rosdakarya), hlm. 76.
} 
yang telah dibiasakan kehadirannya sehingga pada akhirnya akan membentuk nilai budaya menjadi bertahan keberadaannya menjadi identitas suatu pesantren.

Berbicara tentang pesantren cukup banyak tersebar luas diseluruh pelosok Indonesia. Bahkan, keberadaan pesantren di Indonesia dianggap sebagai pioner dalam perannya memberikan kontribusi di dunia pendidikan. Salah satu wilayah Indonesia yang memiliki pondok pesantren yakni terdapat di Pulau Bangka yang merupakan bagian dari Propinsi Bangka Belitung. Pontren yang terdapat di Pulau Bangka tentunya juga memiliki kebudayaan tertentu yang dipegang sebagai modal untuk dapat mempertahankan eksistensinya di tengah masyarakat.

Kebudayaan yang ada dalam pesantren tersebut adalah ciri dari bagian identitas pesantren itu sendiri.Oleh sebab itu usaha untuk membangun serta mempertahakan kebudayaan tersebut tentunya harus didukung oleh semua elemen dari lingkungan pondok pesantren itu sendiri diantaranya melalui aktivitas -aktivitas komunikasi yang sengaja dibangun atau memang berjalan secara natural karena sudah menjadi kebiasaan. Aktivitasaktivitas komunikasi yang biasa diterapkan dalam lingkungan pesantren maka akan menghasilkan kekhasan suatu pola komunikasi dalam lingkungan pontren tersebut. Pola komunikasi pada umumnya merupakan rangkaian aktivitas komunikasi yang terulang, sama, dalam waktu yang lama dan membentuk pola yang rutin dan biasa dilakukan oleh anggota dalam lingkungan tersebut.

Apalagi untuk mempertahankan keberadaan pesantren yang sudah belasan tahun seperti Pontren Nurul Muhibbin hingga puluhan tahun seperti pesantren Al-Islam Kemuja dan Nurul Ihsan Baturusa tentunya perlu usaha yang maksimal untuk menjaga budaya tersebut. Budaya dalam sebuah pesantren yang telah mengakar akan menjadi sebuah identitas. Dari identitas itulah akan tertanam sebuah brand sehingga menjadi nilai jual dari sebuah pesantren. Pola komunikasi yang berulang akan membentuk dan mempertahankan budaya pesantren itu sendiri. Seperti apa gambaran pola komunikasi dalam mempertahankan budaya diketiga pesantren ini? Penulis akan mengulas tentang ini dan akan membatasi tulisan ini dari hasil temuan penulis sesuai dengan masa kepemimpinan terbaru/yang berlaku diketiga pontren ini.

Berdasarkan latar belakang masalah ini, maka rumusan masalah dari penelitian ini adalah: (1) Seperti apa bentuk budaya pesantren yang ada di Pulau Bangka? (2) Bagaimana 
pemetaan pola komunikasi untuk mempertahankan budaya pesantren di Pulau Bangka? (3) Bagaimana deskripsi penerapan pola komunikasi untuk mempertahankan budaya pesantren di Pulau Bangka?; dengan tujuan penelitian yaitu (1) Untuk mendeskripsikan budaya pesantren di Pulau Bangka (2) Untuk memetakan pola komunikasi dalam mempertahankan budaya pesantren di Pulau Bangka (3) Untuk mendeksripsikan penerapan pola komunikasi dalam mempertahankan budaya pesantren di Pulau Bangka.

\section{B. Telaah Pustaka}

Penelitian yang relevan terkait dengan penelitian ini adalah Penelitian yang dilakukan oleh Rudi Hartono yang berjudul Pola Komunikasi di Pesantren: Studi tentang Model Komunikasi antara Kiai, Ustadz dan Santri di Pondok Pesantren TMI Al-Amien Prenduan. Adapun kesimpulan dari penelitian adalah sebagai berikut: Proses komunikasi antara kiai, ustadz dan santri terjadi pada saat acara-acara pondok, seperti: penerimaan santri baru, acara Dialog Jum'at, pelantasi (pekan perkenalan dan orientasi), acara di radio (Rasda FM), ketika menangani santri yang bermasalah arus komunikasi yang digunakan dua arah, dengan menyepakati model komunikasi De Vito. Ketika cara pelantasi, arus komunikasi yang digunakan satu arah, dengan menyentuh model komunikasi yang dikembangkan oleh Harold Dwight Lasswell. ${ }^{4}$

Penelitian selanjutnya dilakukan oleh Irmulan Sati dkk dengan judul Pola Komunikasi dalam Membentuk Spirit Ekonomi Kreatif dan Nilai Budaya Lokal pada Pengrajin Batik Terogong Jakarta Selatan dan Batik Cual Pangkal Pinang. Kesimpulan dari penelitian ini adalah'Terdapat tiga pola situasi komunikasi dalam studi kasus ini, yakni pertama situasi komunikasi yang melibatkan diri dengan nilai warisan leluhur dan keluarga. Kedua, situasi komunikasi yang melibatkan diri pada aspek nilai warisan leluhur, keluarga dan pemerintah daerah serta organisasi kemasyarakatan. Ketiga, situasi komunikasi yang melibatkan diri pada organisasi kemasyarakatan. Fokus penelitian pola dan alat komunikasi para pengrajin batik. Pola komunikasi yang tercipta antara para pengrajin batik dapat dipolakan dalam bentuk, pertama, pola komunikasi antara pengrajin. Kedua, pola komunikasi antara keluarga, ketiga, pola komunikasi dengan komunitas dan konsumen.Media komunikasi yang terjalin dalam interaksi antara pengrajin, umumnya dilakukan dengan

\footnotetext{
${ }^{4}$ https://www.researchgate.net/
} 
komunikasi face to face saat bertemu dengan pemerintah, konsumen dan keluarga.Sedangkan media komunikasi lainnya dapat melalui media sosial: facebook, whatsapp, mengundang para blogger, sekaligus memiliki website untuk mensosialisasikan produk produk batik yang disiapkan dalam bentuk konten tertentu.

Fokus penelitian ketiga, komponen kompetensi komunikasi para pengrajin batik. Bagi pengrajin batik Terogong, kompetensi komunikasi masih terpusat pada pemilik.Pengrajin batik Cual, formatnya sudah berbeda, kompetensi komunikasi tidak hanya terpusat kepada pemilik industri batik, yakni Ibu Ishadi dan Ibu Maslina, namun juga kepada anggota pengrajin.

Fokus penelitian keempat, pola fikir (world view) para pengrajin batik dalam membentuk spirit ekonomi kreatif dan menjaga eksistensi nilai budaya lokal. Dari hasil kajian kepada ketiga objek studi diatas, maka dapat dipetakan bahwa pola pikir (world view) ketiganya, sebagai pemilik dan pengusaha wanita, baik Mpok Laela, Ibu Ishadi dan Ibu Maslina, terdapat kesamaan, yakni sama sama ingin melestarikan nilai budaya lokal yang menjadi andalan mereka dalam mengembangkan batik sekaligus sama sama menciptakan ekonomi kreatif yang bernilai guna bagi komunitas di sekitarnya. ${ }^{5}$

Penelitian ketiga dilakukan oleh Fajar Hidayaturrochman dengan judul penelitian Pola Komunikasi Kyai dan Santri dalam Proses Pembelajaran di Pondok Pesantren Darul Muzani Karangjati Kecamatan Sampang Kabupaten Cilacap. Dengan kesimpulan dari penelitian ini adalah pola komunikasi yang digunakan kyai atau pengasuh pondok pesantren Darul Muzani terhadap santrinya dalam proses pembelajaran dari berbagai bidang materi pelajaran Kyai menggunakan pola komunikasi intruksional merupakan komunikasi langsung dengan menggunakan lisan seperti mengintruksikan santri membaca kitab, mendemonstrasikan cara wudhu, kemudian komunikasi antar pribadi (interpersonal) misalnya santri berkonsultasi kepada kyai mengenai materi pengajian kitab tertentu, dan komunikasi kelompok kecil dimana sejumlah santri terlibat antara satu dengan yang lain dalam satu pertemuan yang bersifat tatap muka.

\footnotetext{
5 Irmulan, Sati, dkk., 2017." Pola Komunikasi dalam Membentuk Spirit Ekonomi Kreatif dan Nilai Budaya Lokal pada Pengrajin Batik Terogong Jakarta Selatan dan Batik Cual Pangkal Pinang”, Prosiding, Pusat Riset Universitas Mercu Buana.
} 
Pola komunikasi yang digunakan oleh kyai atau pengasuh pondok pesantren Darul Muzani dalam proses pembelajaran yang terjadi di luar rungan adalah dengan menggunakan pola komunikasi intruksional, pola komunikasi antar pribadi dan pola komunikasi kelompok kecil. Proses pembelajaran di luar jam pelajaran merupakan kegiatan untuk menerapkan apa yang para santri terima ketika pembelajaran kitab kuning.Mereka diarahkan melakukan kegiatan-kegiatan yang bersifat positif, seperti kerja keras, tak kenal putus asa, melatih kepercayaan diri untuk tampil sebagai orang yang sederhana, mematuhi aturanaturan syari'at, suka menolong dan lain sebagainya.

Metode yang digunakan dalam proses pembelajaran yaitu metode tanya jawab digunakan untuk mengingat kembali materi yang telah disampaikan, kemudian metode penugasan digunakan agar santri setelah mengaji dapat belajar lagi karena diberi tugas, kemudian metode menyimak digunakan untuk menjelaskan isi materi, kemudian metode demonstrasi santri dituntut untuk mendemonstrasikan teori yang disampaikan oleh kyai, dan metode motivasi digunakan pada akhir pembelajaran agar santri termotivasi dalam menuntut ilmu. ${ }^{6}$

\section{Teori Interaksi Simbolik}

Interaksionisme simbolis adalah pemikiran yang berfokus pada cara-cara manusia membentuk makna dan susunan dalam masyarakat melalui percakapan. Barbara Ballis Lal meringkaskan pemikiran gerakan ini yakni: ${ }^{7}$

- Manusia membuat keputusan dan bertindak sesuai dengan pemahaman subjektif mereka terhadap situasi ketika mereka menemukan diri mereka;

- Kehidupan sosial terdiri dari proses-proses interaksi daripada susunan sehingga terus berubah;

- Manusia memahami pengalaman mereka melalui makna-makna yang ditemukan dalam simbol-simbol dari kelompok utama mereka dan bahasa merupakan bagian penting dalam kehidupan sosial;

\footnotetext{
${ }^{6}$ http:/ / repository.iainpurwokerto.ac.id/2354/

${ }^{7}$ Stephen W Littlejohn dan Karen A Foss, 2009, Teori Komunikasi, terj: Theories of Human Communication (Jakarta: Penerbit Salemba Humanika), hlm. 231-232
} 
- Dunia terbentuk dari objek-objek sosial yang memiliki nama dan makna yang ditentukan secara sosial;

- Tindakan manusia didasarkan pada penafsiran mereka, dimana objek dan tindakan yang berhubungan dalam situasi yang dipertimbangkan dan diartikan;

- Diri seorang merupakan sebuah objek yang signifikan dan layaknya semua objek sosial, dikenalkan melalui interkasi sosial dengan orang lain.

\section{Etnografi Komunikasi}

Etnografi komunikasi adalah metode aplikasi etnografi sederhana dalam pola komunikasi sebuah kelompok. Pada ranah etnografi komunikasi yang dilihat adalah: 1) pola komunikasi yang digunakan oleh sebuah kelompok; 2) mengartikan semua kegiatan komunikasi ini ada untuk kelompok; 3) kapan dan dimana anggota kelompok menggunakan semua kegiatan ini; 4) bagaimana praktik komunikasi menciptakan sebuah komunitas; dan 5) keragaman kode yang digunakan oleh sebuah kelompok. Dell Hymes seorang antropolog memberi saran bahwa terdapat sembilan hal yang dapat digunakan untuk membandingkan budaya yang berbeda yakni: ${ }^{8}$

- Logat atau pola komunikasi yang dikenali dari anggota kelompok;

- Kelancaran ideal pembicara atau apa yang mendasari seorang pelaku komunikasi patut dicontoh;

- Komunitas percakapan atau kelompok dan segala batasannya;

- Situasi percakapan atau semua waktu saat komunikasi dianggap tepat dalam komunitas;

- Peristiwa percakapan atau kejadian apa yang dianggap menjadi komunikasi bagi anggota kelompok;

- Speech act atau serangkaian perilaku spesifik yang diambil sebagai sebuah contoh komunikasi dalam sebuah peristiwa percakapan;

- Komponen speech act atau apa yang dianggap menjadi elemen dari sebuah tindakan komunikatif;

- Aturan bicara dalam komunitas atau tuntunan atau standar dimana perilaku komunikatif diputuskan;

\footnotetext{
${ }^{8}$ Ibid., hlm. 460-461.
} 
- Fungsi bicara dalam komunitas atau komunikasi apa yang diyakini menuntaskan.

\section{E. Model Komunikasi}

Model adalah suatu gambaran yang sistematis dan abstrak, dimana menggambarkan potensi-potensi tertentu yang berkaitan dengan berbagai aspek dari sebuah proses. ${ }^{9}$ Model komunikasi adalah representasi fenomena komunikasi dengan menonjolkan unsur-unsur terpenting guna memahami suatu proses komunikasi. ${ }^{10}$

\section{F. Budaya}

\section{Definisi Kebudayaan}

Kata kebudayaan berasal dari bahasa Sansekerta buddhayah yang merupakan bentuk jamak kata "buddhi” yang berarti budi atau akal. Kebudayaan diartikan sebagai hal-hal yang bersangkutan dengaan budi atau akal.Menurut antropolog E. B. Taylor memberikan definisi kebudayaan adalah kompleks yang mencakup pengetahuan, kepercayaan, kesenian, moral,hukum, adat istiadat dan lain kemampuan-kemampuan serta kebiasaan-kebiasaan yang didapatkan oleh manusia sebgai anggota masyarakat. Sedangkan menurut Selo Soemardjan dan Soelaeman Soemardi mendefinisikan kebudayaan sebagai semua hasil karya, rasa dan cipta masyarakat. ${ }^{11}$

\section{Unsur-Unsur Kebudayaan}

Terdapat tujuh unsur kebudayaan yang dianggap sebagai cultural universals yakni dimana kebudayaan ini berlaku untuk banyak orang di seluruh dunia meliputi:

- Peralatan dan perlengkapan hidup manusia (pakaian perumahan,alat-alat rumah tangga, senjata, alat-alat produksi, transpor dan sebagainya);

- Mata pencaharian hidup dan sistem-sistem ekonomi (pertanian, peternakan, sistem produksi, sistem distribusi dan sebagainya);

- Sistem kemasyarakatan (sistem kekerabatan, organisasi politik, sistem hukum, sistem perkawinan);

- Bahasa (lisan maupun tertulis);

\footnotetext{
${ }^{9}$ Hafied Cangara, Pengantar Ilmu Komunikasi, (Jakarta: PT Raja Grafindo Persada, 2018.), hlm. 37. 2004), hlm. 113

10 Dani Vardiansyah, Pengantar Ilmu Komunikasi Pendekatan Taksonomi Konseptual (Jakarta: Ghalia Indonesia,

${ }^{11}$ Soerjono Soekanto dan Budi Sulistyowati, Sosiologi Suatu Pengantar Edisi Revisi (Jakarta: PT Raja Grafindo Persada, 2015), hlm. 148-149.
} 
- Kesenian (seni rupa, seni suara, seni gerak dan sebagainya);

- Sistem pengetahuan;

- Religi (sistem kepercayaan). ${ }^{12}$

Kebudayaan memiliki tiga wujud yakni:

- Wujud kebudayaan sebagai suatu kompleks dari ide-ide, gagasan, nilai-nilai, normanorma, peraturan dan sebagainya. Wujud dalam hal ini bersifat abstrak, tidak dapat diraba atau difoto. Lokasinya ada di dalam kepala-kepala, atau dengan perkataan lain dalam alam pikiran warga masyarakat di mana kebudayaan bersangkutan itu hidup. Ideide yang berkembang dalam masyarakat tidak lepas antara satu dengan yang lainnya melainkan berkaitan menjadi suatu sistem. Wujud ini lebih akrab disebut dengan adat istiadat.

- Wujud kebudayaan sebagai suatu kompleks aktivitas serta tindakan berpola dari manusia dalam masyarakat. Wujud ini dikenal dengan istilah sistem sosial. Sistem sosial ini terdiri dari aktivitas-aktivitas manusia-manusia yang berinteraksi dalam waktu ke waktu menurut pola-pola tertentu yang berdasarkan adat tata kelakuan.

- Wujud kebudayaan sebagai benda-benda hasil karya manusia. Kebudayaan ini disebut dengan kebudyaan fisik. Kebudayaan ini adalah hasil dari aktivitas, perbuatan dan karya semua dalam masyarakat yang sifanya konkret dan berupa benda-benda atau hal-hal yang dapat diraba, dilihat dan di foto.

Ketiga hal ini saling berkaitan tidak dapat dipisahkan dimana kebudayaan adalah hal yang idea dan adat istiadat mengatur dan memberi arah kepada tindakan dan karya manusia. ${ }^{13}$

\section{G. Pondok Pesantren}

\section{Definisi Pesantren}

Secara terminologis, pesantren didefinisikan sebagai lembaga pendidikan tradisional Islam untuk mempelajari, memahami, mendalami, menghayati dan mengamalkan ajaran

\footnotetext{
12 Ibid., hlm. 152.

13 Koentjaraningrat, Pengantar Ilmu Antropologi (Jakarta: PT Rineka Cipta, 1990), hlm. 186-188.
} 
Yera Yulista

Islam dengan menekankan pentingnya moral keagamaan sebagai pedoman perilaku seharihari. ${ }^{14}$

\section{Fungsi dan Misi Pesantren}

Pondok pesantren memiliki fungsi ganda yakni: 1) Sebagai lembaga keagamaan yang berfungsi menyebarluaskan dan mengembangkan ilmu-ilmu keislaman; 2) Pesantren berfungsi sebagai lembaga pengkaderan yang telah berhasil mencetak kader umat dan kader bangsa; 3) Pesantren juga berfungsi sebagai agen reformasi sosial yang menciptakan perubahan dan perbaikan dalam kehidupan masyarakat.

\section{Nilai-nilai Dasar Pesantren:}

\section{Nilai-nilai dasar Agama Islam}

Apapun bentuk aktivitas yang ada di pondok esantren harus mengacu dan merujuk pada nilai-nilai dasar pesantren yang sumber primernya adalah wahyu, Al Qur'an dan Hadits dan tercermin secara praksis dalam aqidah, syari'ah dan akhlaqul karimah.

\section{Nilai-nilai budaya Bangsa}

Implementasi nilai-nilai dasar Islam harus disesuaikan secara harmonis dan akamodati dengan kultur, tradisi dan budaya lokal (masyarakat sekitar) serta bangsa Indonesia secara umum, tanpa harus menafikan prinsip-prinsip dasar pesantren.

\section{Nilai-nilai Dasar Pendidikan}

Pondok pesantren memiliki tugas mendirikan pendidikan dan pengajaran kepada umat agar menjadi Khairo Ummatin, Khair al-Nas 'Anfa'uhum li al-Nas yakni dimana umat Islam yang terbaik, umat yang berkulitas dan bermanfaat bagi masyarakat luas secara imaniah, ilmiah dan amaliah.

\section{Nilai-nilai Perjuangan dan Pengorbanan}

Komunitas pesantren (kiyai, keluarga kyai, ustadz, pengurus, dan staf kantor atau karyawan) harus benar-benar menyadari bahwa tugasnya di pondok pesantren perjuangan besar yang membutuhkan pengorbanan lahir dan batin. ${ }^{15}$ $57-58$.

14 Muljono Damopolii, Pesantren Modern IMMIM Pencetak Muslim Modern (Jakarta: Rajawali Pers, 2001), hlm.

${ }^{15}$ Rusydi Sulaiman dkk, Diorama Pendidikan Islam (Yogyakarta: Idea Press Yogyakarta, 2012), hlm. 22-24. 
Pola Komunikasi dalam Mempertahankan Eksistensi Budaya Pesantren di Pulau Bangka

\section{H. Metode Penelitian}

Penelitian yang berjudul Pola Komunikasi dalam Mempertahankan Eksistensi Budaya Pesantren di Pulau Bangka menggunakan penelitian deskriptif dengan pendekatan kualitatif. Metode deskriptif kualitatif tidak jarang melahirkan apa yang disebut Sltiiz, Wrightsman dan Cook sebagai penelitian yang insightmulating, yakni peneliti terjun ke lapangan tanpa dibebani atau diarahkan teori. Penelitian ini bebas mengamati objeknya, menjelajah dan menemukan wawassan-wawasan baru sepanjang penelitian.Penelitiannya terus menerus mengalami reformulasi dan redireksi ketika informasi-informasi baru ditemukan. ${ }^{16}$

Objek sasaran dalam penelitian ini adalah pemimpin dan atau pengelola pesantren, pendidik dan santri/santriwati yang tinggal/mondok dalam lingkungan pesantren. Lokasi atau tempat penelitian ini akan dilakukan di tiga Pondok Pesantren yang berdiri Pulau Bangka dan masih bertahan keberadaannya sampai sekarang yakni Pontren Al Islam Kemuja, Nurul Ihsan Baturusa dan Nurul Muhibbin Kemuja. Sumber data dalam penelitian ini adalah sumber data primer dan sumber data sekunder.

Sumber data primer berasal dari wawancara kepada sejumlah narasumber yang dianggap dapat mewakili jawaban penelitian dalam hal ini Pimpinan Pontren, ustadz, ustadzah, dan santri. Sedangkan sumber data sekunder nantinya berasal dari dokumen yang berkaitan dengan objek penelitian diantarnya buku teori, dokumen pesantren, foto dan internet.

\section{Hasil Penelitian dan Pembahasan}

\section{Budaya Dan Penerapan di Pontren Pulau Bangka}

Budaya memiliki berasal dari bahasa Sansekerta yakni “buddhayah” yang merupakan bentuk jamak kata “buddhi” yang berarti budi atau akal. Kebudayaan dapat diartikan sebagai hal-hal yang bersangkutan dengaan budi atau akal.Definisi lain diungkapkan oleh E. B. Taylor yang mengatkan bahwa kebudayaan adalah kompleks yang mencakup pengetahuan, kepercayaan, kesenian, moral, hukum, adat istiadat, dan lain kemampuan-kemampuan serta

\footnotetext{
${ }^{16}$ Elvinaro Ardianto, Metodologi Penelitian untuk Public Relations Kuantitatif dan Kualitatif (Bandung: Simbiosa Rekatama Media, 2010), hlm. 60.
} 
kebiasaan-kebiasaan yang didapatkan oleh manusia sebagai anggota masyarakat. Selo Soemardjan dan Soelaeman Soemardi mendefinisikan kebudayaan sebagai semua hasil karya, rasa dan cipta masyarakat. ${ }^{17}$

Secara lebih terperinci terdapat tujuh unsur kebudayaan yang dianggap sebagai cultural universals atau hal-hal umum dimana kebudayaan ini berlaku untuk banyak orang di seluruh dunia meliputi: Pertama, Peralatan dan perlengkapan hidup manusia (pakaian, perumahan, alat-alat rumah tangga, senjata, alat-alat produksi, transportasi dan sebagainya). Kedua, Mata pencaharian hidup dan sistem-sistem ekonomi (pertanian, peternakan, sistem produksi, sistem distribusi dan sebagainya). Ketiga, Sistem kemasyarakatan (sistem kekerabatan, organisasi politik, sistem hukum, sistem perkawinan). Keempat, Bahasa (lisan maupun tertulis). Kelima, Kesenian (seni rupa, seni suara, seni gerak dan sebagainya). Keenam, Sistem pengetahuan. Ketujuh, Religi (sistem kepercayaan). ${ }^{18}$

Ada juga pendapat lain yang mengelompokkan budaya dalam tiga wujud kebudayaan yakni: 1) Wujud kebudayaan sebagai suatu kompleks dari ide-ide, gagasan, nilai-nilai, norma-norma, peraturan dan sebagainya. Wujud dalam hal ini bersifat abstrak, tidak dapat diraba atau difoto. Lokasinya ada di dalam kepala-kepala, atau dengan perkataan lain dalam alam pikiran warga masyarakat di mana kebudayaan bersangkutan itu hidup. Ide-ide yang berkembang dalam masyarakat tidak lepas antara satu dengan yang lainnya melainkan berkaitan menjadi suatu sistem. Wujud ini lebih akrab disebut dengan adat istiadat. 2) Wujud kebudayaan sebagai suatu kompleks aktivitas serta tindakan berpola dari manusia dalam masyarakat. Wujud ini dikenal dengan istilah sistem sosial. Sistem sosial ini terdiri dari aktivitas-aktivitas manusia-manusia yang berinteraksi dalam waktu ke waktu menurut polapola tertentu yang berdasarkan adat tata kelakuan. 3) Wujud kebudayaan sebagai bendabenda hasil karya manusia. Kebudayaan ini disebut dengan kebudayaan fisik. Kebudayaan ini adalah hasil dari aktivitas, perbuatan dan karya semua dalam masyarakat yang sifanya konkret dan berupa benda-benda atau hal-hal yang dapat diraba, dilihat dan di foto.Ketiga hal ini saling berkaitan tidak dapat dipisahkan dimana kebudayaan adalah hal yang ideal dan adat istiadat mengatur dan memberi arah kepada tindakan dan karya manusia. ${ }^{19}$

\footnotetext{
${ }^{17}$ Soerjono Soekanto dan Budi Sulistyowati, Sosiologi Suatu Pengantar Edisi Revisi, hlm. 148-149.

18 Ibid., hlm. 152.

${ }^{19}$ Ibid., hlm. 186-188.
} 


\title{
Pola Komunikasi dalam Mempertahankan Eksistensi Budaya Pesantren di Pulau Bangka
}

\author{
Berikut deskrispi system budaya yang ada di Pesantren Al Islam Kemuja, Nurul Ihsan
}

Baturusa dan Nurul Muhibbin Kemuja.

Tabel 1.

Sistem Budaya di Pesantren Al-Islam Kemuja

\begin{tabular}{|c|c|c|c|}
\hline No & Jenis Budaya & Penerapan Budaya & Keterangan \\
\hline 1. & Peralatan Hidup & $\begin{array}{ll}\text { 1. } & \text { Pakaian } \\
\text { 2. } & \text { Bel } \\
\text { 3. } & \text { Kendaraan operasional }\end{array}$ & $\begin{array}{l}\text { 1. Pakaian yang digunakan untuk laki-laki berupa sarung, koko, } \\
\text { peci sedangkan wanita berupa jilbab, gamis. Dipesantren ini juga } \\
\text { terdapat almamater yang menggambarkan identitas sebagai } \\
\text { santri Al Islam Kemuja. }\end{array}$ \\
\hline
\end{tabular}

2. Bel digunakan sebagai alat kode/ penanda yang berlaku di sekolah misalkan untuk menandakan waktu istirahat santri

3. Kendaraan operasional diantaranya berupa mobil

\begin{tabular}{|c|c|c|c|c|}
\hline 2. & Sistem Ekonomi & $\begin{array}{ll}\text { 1. } & \text { Beroperasinya Toserba } \\
\text { 2. } & \text { Adanya Lembaga } \\
& \text { Kesejahteraan Desa } \\
& \text { (LDK) } \\
\text { 3. } & \text { Berdirinya kantin } \\
\end{array}$ & & $\begin{array}{l}\text { Toserba didirikan untuk memenuhi kebutuhan sehari-hari para } \\
\text { santri atau pihak lain yang ingin berbelanja. } \\
\text { Lembaga ini ikut memberi bantuan dalam operasionalisasi } \\
\text { pesantren. }\end{array}$ \\
\hline 3. & $\begin{array}{l}\text { Sistem } \\
\text { Kemasyarakatan }\end{array}$ & $\begin{array}{ll}\text { 1. } & \begin{array}{l}\text { Adanya budaya gotong } \\
\text { royong/saling bantu- } \\
\text { membantu. }\end{array} \\
\text { 2. } & \begin{array}{l}\text { Peraturan untuk para } \\
\text { santri }\end{array} \\
\text { 3. Adanya pimpinan } \\
\text { 4. Adanya perkumpulan } \\
\text { 5. Adanya kehidupan } \\
\text { saling menghargai } \\
\text { antara pihak yang ada } \\
\text { didalam pesantren } \\
\text { 6. } \text { Budaya antri }\end{array}$ & 5. & $\begin{array}{l}\text { Gotong royong dapat diterapkan dalam kerja bakti } \\
\text { membersihkan pesantren, Untuk Hubungan dengan pihak luar } \\
\text { jika ada warga Desa Kemuja yang meninggal dunia dari keluarga } \\
\text { tidak mampu maka pontren memberikan bantuan dari hari } \\
\text { pertama hingga ke tujuh. } \\
\text { Peraturan yang dibuat untuk para santri yang dituangkan dalam } \\
\text { aturan tertulis baik yang tertulis dalam buku pedoman ataupun } \\
\text { dipajang atau mengatur adab ketika berhadapan dengan } \\
\text { guru,adanya juga peraturan tentang batasan komunikasi antara } \\
\text { santri dengan santriwati } \\
\text { Peran pimpinan disini sangat penting dalam membantu } \\
\text { memimpin berjalannya system di pesantren ini } \\
\text { Perkumpulan bisa dibentuk jika ada hal yang penting harus } \\
\text { dibicarakan dalam forum rapat internal pontren, ada juga } \\
\text { perkumpulan para santri dengan istilah Muhadasah (kegiatan } \\
\text { bercakap-cakap menggunakan bahasa Arab) } \\
\text { Tergambar adanya saling komunikasi antara para santri, saling } \\
\text { menjaga kearaban. } \\
\text { Budaya ngantri misalkan berlaku bagi santri yang akan makan }\end{array}$ \\
\hline 4. & Bahasa & $\begin{array}{ll}\text { 1. } & \text { Lisan } \\
\text { 2. } & \text { Tulisan } \\
\text { 3. } & \text { Pesan Nonverbal }\end{array}$ & & $\begin{array}{l}\text { Bahasa yang digunakan di dalam Pondok Pesantren } \\
\text { (asrama/kelas) ini terdiri dari Bahasa Indonesia, Bahasa Arab, } \\
\text { Bahasa Inggris serta Bahasa Daerah Pulau Bangka } \\
\text { Komunikasi lisan digunakan dalam memberikan nasihat } \\
\text { biasanya menggunakan bahasa daerah. } \\
\text { Komunikasi tulisan berisi pesan tentang peraturan/tata tertib } \\
\text { formal,atau peraturan perilaku yang dipajang yang berbahasa } \\
\text { Arab (diambil dari Al Quran/Al Hadits) dan diterjemahkan } \\
\text { dalam Bahasa Indonesia, komunikasi tulisan juga berlaku antar } \\
\text { santri (santri dan santriwati) yang ingin berkirim surat dengan } \\
\text { catatan akan dizinkan jika memang hal ini sangat penting sekali. } \\
\text { Adalagi media tulisan lain dalam pontren ini yaknimading untuk } \\
\text { santri dan pengumuman-pengumuman. } \\
\text { Pesan Nonverbal juga terlihat dari almamater santri, ada loggo } \\
\text { pontren juga yang muncul dialmamater menggambarkan } \\
\text { identitas pontren. }\end{array}$ \\
\hline 5. & Kesenian & $\begin{array}{l}\text { Ada beberapa jenis seni yang } \\
\text { ada di Pondok Pesantren ini } \\
\text { yakni rudat,hadrah,barzanzi } \\
\text { sedangkan untuk olahraga } \\
\text { diantaranya football/ bola } \\
\text { kaki }\end{array}$ & & $\begin{array}{l}\text { ak kegiatan seni dipesantren ini ada pada saat acara-acara tertentu } \\
\text { dilombakan }\end{array}$ \\
\hline 6. & $\begin{array}{l}\text { Sistem } \\
\text { Pengetahuan }\end{array}$ & $\begin{array}{l}\text { 1. Tulis baca AlQuran } \\
\text { untuk kurikulum } \\
\text { 2. Menggunakan } \\
\text { Kurikulum } 13\end{array}$ & \multicolumn{2}{|r|}{$\begin{array}{l}\text { Pengetahuan pontren ini melibatkan kurikulum tulis baca Al Quran } \\
\text { selain itu melibatkan para ustadz/ustadzah mengajar sesuai dengan } \\
\text { spesifikasi jenjang pendidikan masing-masing }\end{array}$} \\
\hline
\end{tabular}




\begin{tabular}{|c|c|c|c|}
\hline No & Jenis Budaya & Penerapan Budaya & Keterangan \\
\hline 7. & Religi & $\begin{array}{l}\text { 1. Budaya Maulid } \\
\text { 2. Adanya pelajaran Fiqh, } \\
\text { Tauhi, Akhlak Tasawuf, } \\
\text { Nahwu Sharaf } \\
\text { 3. Adanya ekstrakurikuler } \\
\text { khusus keagamaan }\end{array}$ & Budaya ini paling terkenal disini adalah budaya maulid \\
\hline
\end{tabular}

Gambar tabel di atas adalah diantara gambaran sistem budaya yang berlaku di Pesantren Al Islam Kemuja. Apabila melihat Sistem kebudayaan yang berlaku di Pondok Pesantren Al Islam ini budaya-budaya yang ada saling berkaitan satu sama lain. Adanya sejumlah peraturan yang merupakan bagian dari sistem kemasyarakatan dapat mengingkat sub sistem-sistem yang lainnya. Misalkan saja sistem peraturan yang berlaku harus disampaikan oleh system bahasa agar peraturan dapat ditaat.

Selain itu, peran pimpinan begitu terlihat dalam mempertahankan budaya yang ada dipontren ini adanya para santri selalu dibekali dengan nasihat sehingga dapat menjalani hidup menjadi baik. Untuk mengontrol perilaku para santri disini tim guru menunjuk santri terpilih menjadi Jasus. Jasus adalah istilah yang digunakan dipontren ini untuk santri yang ditunjuk untuk "mematai" para santri yang melanggar aturan. Syarat terpilih menjadi Jasus adalah santri yang dinilai guru memiliki tanggung jawab, patuh terhadap aturan. Eksistensi budaya pesantren juga ditopang oleh perekonomian secara mandiri diantaranya mendrikan toserba, kantin dan operasional pesantren juga dibantu oleh Lembaga Kesejahteraan Desa.

Hal lain yang menarik sistem yang berlaku di pondok pesantren ini tidak hanya mengatur perilaku antara pihak internal di dalam lingkungan pesantren saja namun juga berlaku/berimbas dalam system membina interaksi dengan pihak yang ada diluar pondok pesantren khusunya untuk masyarakat yang berada di desa yang sama yakni Desa Kemuja Kabupaten Bangka. Pada kesimpulannya, Pontren Al Islam Kemuja tetap berusaha mempertahankan nilai budaya yang sudah lama terbentuk namun tidak menutup kemungkinan dapat mengadopsi budaya baru jika memang dinilai cukup memberi kemaslahatan yang baik untuk Pontren Al Islam.

Tabel 2.

Sistem Budaya di Pesantren Nurul Ihsan Baturusa

\begin{tabular}{|c|c|c|c|}
\hline No & Jenis Budaya & Penerapan Budaya & Keterangan \\
\hline 1. & Peralatan Hidup & $\begin{array}{ll}\text { 1. } & \text { Gedung } \\
\text { 2. } & \text { Mobil operasional } \\
\text { 3. } & \text { Pakaian }\end{array}$ & $\begin{array}{l}\text { 1. Gedung pesantren adalah diantara perlengkapan hidup } \\
\text { yang sekarang mengalami perubahan karena adanya } \\
\text { renovasi. } \\
\text { 2. Mobil operasional digunakan untuk aktivitas sehari-hari } \\
\text { pesantren. } \\
\text { 3. Untuk laki-laki menggunakan jubah untuk hari jumat, } \\
\text { dan dalam keseharian menggunakan kain sarung } \\
\text { sedangkan wanita menggunakan jilbab dan gamis }\end{array}$ \\
\hline
\end{tabular}




\section{Pola Komunikasi dalam Mempertahankan Eksistensi Budaya Pesantren di Pulau Bangka}

\begin{tabular}{|c|c|c|c|}
\hline No & Jenis Budaya & Penerapan Budaya & Keterangan \\
\hline 2. & Sistem Ekonomi & $\begin{array}{l}\text { 1. Perkebunan kelapa sawit } \\
\text { 2. Ada kantin } \\
\text { 3. Ada koperasi } \\
\text { 4. Mendapat sumbangan } \\
\text { dari donator } \\
\text { 5. Mendapat bantuan dari } \\
\text { ikatan alumni PPNI }\end{array}$ & $\begin{array}{l}\text { Diantara system ekonomi yang ada ini ikut berperan dalam } \\
\text { membantu operasional pesantren. Koperasi adalah diantara } \\
\text { usaha lembaga untuk menjual keperluan harian santri. Selain } \\
\text { itu juga terdapat perkebunan sawit yang dipanen setiap dua } \\
\text { minggu sekali dan untuk kedepan ada renacna untuk } \\
\text { berkebun ubi }\end{array}$ \\
\hline 3. & Sistem Kemasyarakatan & $\begin{array}{l}\text { 1. Adanya sosok } \\
\text { pemimpin. } \\
\text { 2. Adanya Hubungan } \\
\text { kekeluargaan yang baik. } \\
\text { 3. Adanya perkumpulan. } \\
\text { 4. Peraturan dipontren ada } \\
\text { yang berupa aturan } \\
\text { tertulis yang } \\
\text { ditempelkan dibeberapa } \\
\text { sudut pontren atau } \\
\text { aturan lisan yang sifatnya } \\
\text { turun menurun dalam } \\
\text { bentuk adab-adab } \\
\text { tertentu yang berlaku } \\
\text { dipontren. } \\
\text { Sistem sosial berpa } \\
\text { kebersamaan }\end{array}$ & $\begin{array}{l}\text { 1. Sosok pemimpin memiliki pengaruh yang besar dalam } \\
\text { menerapkan system yang berlaku di PPNI } \\
\text { Aturan dalam hubungan antara pihak internal diatur } \\
\text { sedemikian rupa seperti menghormati orangtua, } \\
\text { mengatur etika pembicaraan seperti menggunakan } \\
\text { bahasa yang baik(tidak menggunakan kata-kata } \\
\text { kotor)membina hubungan yang baik sehingga } \\
\text { hubungan mejadi harmonis,peraturan pembatasan } \\
\text { interaksi dengan lawan jenis, mengatur jam tertentu } \\
\text { untuk keluar pondok bagi santri misalkan Senin Kamis } \\
\text { untuk Santriwati dan Santri hari Rabu dan Sabtu namun } \\
\text { tetap dengan pengawasan pihak pontren.Dipontren ini } \\
\text { juga para santri dilarang menggunakan HP. } \\
\text { Selain dikelas PPNI juga sering membentuk } \\
\text { perkumpulan misalkan ketika ada kunjungan tamu, } \\
\text { milad pontren, perkumpulan tiap malam jumat untuk } \\
\text { membaca Yasin, atau perkumpulan dalam rangka } \\
\text { memberikan ceramah, Perkumpulan setelah program } \\
\text { kedinihyaan misalkan fiqh, nahwu sharaf, } \\
\text { Perkumpulan saat adnya latihan berpidato, latihan } \\
\text { tahlilan, latihan ketika belajar Bahasa Inggris dan } \\
\text { Bahasa Arab. Antar pihak internal juga terdapat } \\
\text { perkumpulan misalkan dalam perkumpulan formal } \\
\text { setiap minggu ada perkumpulan dengan setiap lembaga } \\
\text { untuk membahas mutu pembelajaran dalam setiap } \\
\text { bulan ada rapat dengan pimpinan lembaga, dan } \\
\text { pertigabulan sekali ada perkumpulan dengan pihak } \\
\text { yayasan. } \\
\text { Peraturan yang terdapat di pontren terdiri dari } \\
\text { peraturan formal yang disepakati melalui pengurus dan } \\
\text { diumumkan dalam bentuk tempelan-tempelan di kelas, } \\
\text { diasrama, dan tempatakses publik. Selain itu, peraturan } \\
\text { lisan juga dalam bentuk etiket disampaikan melalui } \\
\text { turun-temurun. } \\
\text { Dalam sistem sosial pihak pontren sedang berusaha } \\
\text { menerpkan prinsip pengajar wajib tinggal dilingkungan } \\
\text { pontren sehingga santri dapat melihat keseharian } \\
\text { aktivitas guru }\end{array}$ \\
\hline 4. & Bahasa & $\begin{array}{l}\text { 1. Bahasa yang digunakan } \\
\text { bahasa lisan dan tulisan } \\
\text { baik menggunakan } \\
\text { Bahasa Daerah Bangka, } \\
\text { Bahasa Arab atau } \\
\text { Bahasa Indonesia. } \\
\text { 2. Ada beberapa ciri khas } \\
\text { ucapan tertentu yang } \\
\text { digunakan di PPNI }\end{array}$ & $\begin{array}{l}\text { 1. Bahasa Indonesia digunakan didalam kelas sedangkan } \\
\text { bahasa daerah dilakukan untuk di asrama. Komunikasi } \\
\text { tulisan digunakan dalam bentuk } \\
\text { pengumuman,menuliskan undangan, tulisan di mading } \\
\text { memberikan aturan yang ditempelkan dibeberapa sudut } \\
\text { pontren misalkan shalat tepat waktu, harap melepas } \\
\text { sandal. } \\
\text { 2. Logat yang digunakan untuk kerja bakti disebut roan, } \\
\text { olahraga =furusia, tidur setelah subuh =bangkong, } \\
\text { tidak udzur=suci }\end{array}$ \\
\hline 5. & Kesenian & $\begin{array}{l}\text { 1. Bidang kesenian seperti } \\
\text { hadrah. } \\
\text { 2. Bidang olahraga } \\
\text { diantaranya volley, bulu } \\
\text { tangkis, latihan } \\
\text { memanah, boxing }\end{array}$ & $\begin{array}{l}\text { 1. Untuk hadrah biasanya diselenggrakan pada malam } \\
\text { Jumat, hari besar negara/PHBI, Aadnya kedatangan } \\
\text { tamu/ulama atau acara aqiqah. } \\
\text { 2. Para santri ada yang terlibat dalam mengikuti lomba } \\
\text { dibidang olahrga. Untuk boxing diadakan setiap malam } \\
\text { Rabu, sedangkan untuk olahraga memanah dilakukan } \\
\text { setiap ahad pagi. }\end{array}$ \\
\hline 6. & Sistem Pengetahuan & $\begin{array}{l}\text { 1. Latihan berpidato. } \\
\text { 2. Pelajaran Diniyah }\end{array}$ & $\begin{array}{l}\text { 1. Untuk sistem belajar dapat diterapkan didalam atupun } \\
\text { di luar kelas. }\end{array}$ \\
\hline
\end{tabular}




\begin{tabular}{|c|c|c|c|}
\hline No & Jenis Budaya & Penerapan Budaya & Keterangan \\
\hline & & & $\begin{array}{l}\text { 2. Sistem pengetahuan tergantung dari dari gurumya } \\
\text { masing-masing misalkan adayang dibawa ke } \\
\text { perpustakaan. }\end{array}$ \\
\hline & Religi & 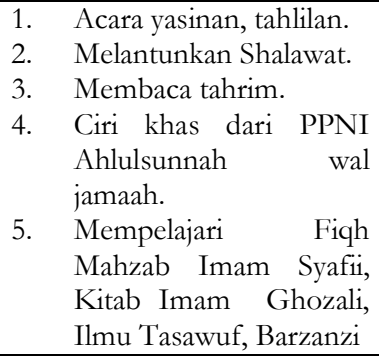 & $\begin{array}{l}\text { 1. Penyelenggaraan yasinan ini biasanya dilakukan pada } \\
\text { malam Jumat. } \\
\text { 2. Pembacaan shalawat biasanya dilakukan sebelum } \\
\text { maghrib. } \\
\text { 3. Pembacaan tahrim dilakukan setelah shalat subuh }\end{array}$ \\
\hline
\end{tabular}

Berkaitan dengan sistem yang ada di Pontren Nurul Ihsan ini ada beberapa jenis budaya yang berlaku berbeda sesuai dengan situasi siapa yang memegang amanah kepemimpinan sehingga memiliki ada keragaman budaya. Pesantren Nurul Ihsan tentunya juga memilki ciri khas system dan pengaturan tertentu guna mempertahankan pontren itu sendiri. Dari temuan dilapangan ada aturan-aturan yang dibuat secara tertulis namun ada juga yang turun temurun sehingga seperti sudah membudaya yang dibicarakan dari generasi ke generasi sehingga tidak perlu untuk dikomunikasikan kembali. Untuk peraturan, juga didesain secara konsisten artinya jika ada santri yang melanggar aturan maka tetap akan diberikan sanksi sesuai dengan prosedur yang ada, dalam hal ini para pendidik di PPNI berusaha menjaga komitmen apa yang diucapkan harus sesuai dengan tindakan yang dilakukan sehingga peraturan akan dikuti oleh para santri.

Perubahan penambahan jumlah pendidik daripada tahun sebelumnya di pontren ini mengindikasikan bahwa pesantren ini tetap bertahan ditengah banyak persaingan pontren yang baru berada di Pulau Bangka ini. Adapun budaya yang masih bertahan dipontren ini adalah tentang nahwu sharaf yakni bagaimana cara membaca kitab kuning.Nilai-nilai keislaman juga selalu diusahakan untuk dipertahankan dipontren ini baik dengan cara disampaikan lewat komunikasi lisan dengan harapan nilai/perilaku keIslaman ini bisa diterapkan bukan hanya dipesantren namun pada saat santri berinteraksi dengan orang ketika berada diluar pesantren. Selain adanya budaya bertahan adanya budaya yang bergeser disini misalkan ada santri yang memilih tidak tinggal di pontren.

Untuk mempertahankan budaya maka ada beberapa langkah yang digunakan yakni oleh pimpinan sangat menyadari harus ada usaha memperbaiki diri dengan berdoa, adanya usaha duduk dimajlis taklim, meminta doa para kyai,mensosialisasikan nilai-nilai budaya saat ada pembelajaran dikelas sehingga para santri dapat mempertahnkan nilai budaya tersebut, membuat forum diskusiberupa dalil-dalil amalan penting yang harus dipraktikan, 


\section{Pola Komunikasi dalam Mempertahankan Eksistensi Budaya Pesantren di Pulau Bangka}

melakukan istighosah, pembacaan barzanzi, masyarakat mengundang pihak ponpes untuk dilibatkan dalam forumdiskusi, aqiqah. Pontren ini juga mengedepankan adab misalkan santri harus menjaga adab menghargai guru tidak hanya didepan guru namun juga dibelakang guru, menghargai tamu dan sebagainya. Pontren Nurul Ihsan juga pada prinsipnya tetap berusaha mempertahankan budaya yang sudah ada, namun jika ada budaya baru yang sesuai dengan prinsip maka tetap akan diambil.

Tabel 3.

Sistem Budaya di Pesantren Nurul Muhibbin Kemuja

\begin{tabular}{|c|c|c|}
\hline No & Jenis Budaya & Penerapan Budaya \\
\hline 1. & Peralatan Hidup & $\begin{array}{ll}\text { 1. } & \text { Pakaian } \\
\text { 2. } & \text { Transportasi : mobil }\end{array}$ \\
\hline 2. & Sistem Ekonomi & $\begin{array}{l}\text { Sumber pencarian: } \\
\text { 1. Perkebunan (sistem tanam tumbuh): } \\
\text { karet, kebun sawit. } \\
\text { 2. Peternakan: walet }\end{array}$ \\
\hline 3. & $\begin{array}{l}\text { Sistem } \\
\text { Kemasyarakatan }\end{array}$ & $\begin{array}{l}\text { 1. Adanya kepatuhan terhadap } \\
\text { pemimpin. } \\
\text { 2. Adanya kehidupan gotong royong. } \\
\text { 3. Peraturan yang dibuat untuk para } \\
\text { santri. } \\
\text { 4. Adanya perkumpulan baik } \\
\text { formal/informal. } \\
\text { 5. Adanya perkumpulan acara } \\
\text { formal/informal. } \\
\text { 6. Adanya sistem pengawasan untuk } \\
\text { 5antridari kakak kelas. } \\
\text { 7. Adanya pilihan mengabdi kepada } \\
\text { masyarakat }\end{array}$ \\
\hline
\end{tabular}

Keterangan

1. Pakaian santri: baju koko, peci, sarung, gamis warna putih.

2. Mobil sebagai kendaraan operasional salah satunya digunakan sebagai alat tranportasi santri untuk shalat Jumat di Desa Kemuja

1. Sistem perekonomian di pesantren ini dikelola oleh koordinator.

2. Peternakan yang focus sekarang adalah sarang burung wallet, dalam hal ini liur walet yang akan dijual menghasilkan pundi kisaran belasan hingga puluhan juta dalam hitungan perkilo

Pemimpin pontren ini begitu dihormati. Selain pimpinan sosok yang berwibawa juga dianggap sebagai motivator misalkan memotivasi santri bahwa hidup tidak hanya berbicara tentang agama tetapi juga cara hidup.Motivasi lain meminta para santri menjaga moral agar dapat hidup berdampingan secara damai.

2. Gotong royong dilakukan setiap hari namun yang wajib dilakukan pada Jumat (hari libur pontren) dalam acara jumat bersih, tolong menolong antar santri atau pengelola pontren yang kehabisan stock makanan maka dibantu dengan membeli beras/ masak bersama. Gotong royong dalam bentuk lain jika ada beberapa santri berasal dari satu keluarga tidak mampu yang ingin bersekolah dipesantren ini maka diberi potongan untuk pembayaran biaya sekolah. Selain itu ada kerjasama dengan semua guru untuk mempertahankan hal-hal yang baik.

3. Peraturan bahwa santri harus tinggal dipontren (mondok)/tidak boleh jadi santri kalong kecuali boleh pulang pada Libur Idul Fitri, Idul Adha, Maulid Nabi, santri tidak boleh menggunakan $\mathrm{HP}$, santri harus datang 30 menit sebelum waktu shalat, santri senior harus membuat jadwal tertentu untuk adik kelas,tidak boleh kedapur diatas jam 10 malam adanya pembatasan interaksi yang sangat ketat antar santri dan santriwati, begitupun antar santri dengan ustadz jika berinteraksi diluar jam sekolah misalkan pada saat dirumah maka santri berinteraksi hanya dari luar rumah ustadz.. Dan apabila ada santri yang melanggar jelas akan diberikan punishment/hukuman. Punishment santri akan digundul/botak atau diminta pulang selama 3 bulan dan orangtua akan dipanggil, jika tidak mampu maka santri diskorsing dikeluarkan dari pesantren. 


\begin{tabular}{|c|c|c|c|}
\hline No & Jenis Budaya & Penerapan Budaya & Keterangan \\
\hline & & & $\begin{array}{l}\text { Peraturan dipontren ini ada yang dituangkan } \\
\text { dalam tulisan/lisan yang dapat diulang setiap hari } \\
\text { untuk mengingatkan santri atau dalam waktu } \\
\text { tertentu. } \\
\text { 4. Perkumpulan dalam bentuk reuni akbar, buka } \\
\text { puasa bersama } 1 \text { tahun sekali untuk memperkuat } \\
\text { silahturahmi, atau pertemuanantara para guru } \\
\text { untuk membahas perkembangam para santri } \\
\text { misalkan membahas kedisiplinan santri,keluh } \\
\text { kesah santri. Untuk informal perkumpulan } \\
\text { dilakuan pada saat makan bersama, perkumpulan } \\
\text { dimasjid, dikelas,pengajian umum misalkan } \\
\text { malam senin } 1 \text { minggu sekali,jika hari Selasa } 2 \\
\text { minggu sekali. Pengajian umum untuk orang } \\
\text { umum yang ingin belajar secara gratis. }\end{array}$ \\
\hline 4. & Bahasa & $\begin{array}{l}\text { 1. Bahasa yang digunakan yakni bahasa } \\
\text { lisan dan tulisan }\end{array}$ & $\begin{array}{l}\text { 1. Bahasa yang digunakan dipontren ini Bahasa } \\
\text { Indonesia, Bahasa Arab digunakan dalam kitab, } \\
\text { papan pengumuman atau peraturan yang } \\
\text { dipajang. Sedangkan Bahasa Daerah (biasa } \\
\text { digunakan dalam percakapan sehari-hari). Untuk } \\
\text { percakapan bahasa Arab sedang direncanakan } \\
\text { untuk diberlakukan kembali. Untuk komunikasi } \\
\text { tulisan dituangkan dalam membuat jadwal } \\
\text { piket,sejumlah peraturan larangan misalkan } \\
\text { untuk tidak merokok, memperbagus pakaian } \\
\text { ketika masuk pesantrenn }\end{array}$ \\
\hline 5. & Kesenian & $\begin{array}{l}\text { 1. Seni seperti Hadrah seperti shalawat, } \\
\text { syair, kaligrafi. } \\
\text { Olahraga: sepak bola, volley, } \\
\text { memancing }\end{array}$ & $\begin{array}{l}\text { Lomba memancing biasanya hanya dilakuakn } \\
\text { pada acara tertentu saja. }\end{array}$ \\
\hline 6. & $\begin{array}{l}\text { Sistem } \\
\text { Pengetahuan }\end{array}$ & $\begin{array}{l}\text { 1. Pelatihan Ceramah. } \\
\text { 2. Sistem menghafal untuk materi } \\
\text { tertentu untuk PR kemudian disetor } \\
\text { hafalannya. } \\
\text { 3. Pengajaran salah satunya untuk } \\
\text { keahlian elektronik, perbengkelan. } \\
\text { 4. Belajar Ilmu Nahwu Sharaf (membaca } \\
\text { kitab kuning) }\end{array}$ & $\begin{array}{l}\text { 1. Latihan berceramah. Untuk santri kelas IV keatas } \\
\text { harus berceramah setiap mereka selesai shalat, } \\
\text { sedangkan untuk tiap minggu latihan bercermah } \\
\text { ditujukan untuk kelas IV ke bawah. } \\
\text { 2. Elektronik misalkan dibidang laptop, perbaikan } \\
\text { listrik }\end{array}$ \\
\hline 7. & Religi & $\begin{array}{l}\text { 1. Pembacaan wirid (berupa doa dan } \\
\text { dzikir). } \\
\text { 2. Latihan berceramah }\end{array}$ & \\
\hline
\end{tabular}

Pontren Nurul Muhibbin adalah pontren yang dikhususkan bagi para santri (pihak laki-laki). Budaya dipontren ini juga sangat kental dalam perilaku saling tolong menolong antar santri baik dalam pekerjaan seperti gotong royong, membuat bangunan, masak bersama dsb.Para santri terlihat sangat didik untuk menjadi pribadi yang mandiri sehingga setelah tidak tinggal dipesantren mereka akan menjadi sosok yang mandiri.Ada hal yang menarik dipesantren ini yakni pihak pontren memberikan peluang bagi santri yang sudah duduk dikelas VI keatas jika ingin mendidik/mengajar dipontren Nurul Muhibbin selama satu tahun sesuai dengan kebijakan pimpinan pontren.

Budaya-budaya dipontren ini tetap terjaga tentunya tidak lepas dari komitmen pendiri pontren ini untuk menjaga keaslian visi misi pontren ini.Hal ini tentunya didukung oleh pengajar begitupun para santri yang ada dipontren ini untuk menjaga nilai dan manajemen sehingga tetap bertahan. Bertahannya system dipesantren ini juga tidak lepas dari bagaimana 
Pola Komunikasi dalam Mempertahankan Eksistensi Budaya Pesantren di Pulau Bangka

hubungan antarsubsitem yang dipaparkan diatas saling didukung agar system pesantren tetap berjalan dengan kuatmisalkan antara system religi dengan system pengetahuan saling berkaitan. Pada prinsipnya budaya pesantren ini ingin terus dipertahankan dengan komitmen yang kuat, jangan sampai terpengaruh hal-hal yang tidak positif, harus berpegang pada argument, harus menghargai sejarah harus hormat pada guru sehingga budaya pontren ini tetap bertahan.

\section{J. Penerapan Pola Komunikasi dalam Mempertahankan Eksistensi Pesantren di Pulau Bangka}

Dari pemaparan diatas peneliti telah menjabarkan deskripsi pemetaan sub system budaya yang berlaku di Pesantren Al -Islam Kemuja, Pontren Nurul Ihsan Baturusa dan Pontren Nurul Muhibbin Kemuja. Peneliti melihat pengelola pesantren dapat mempertahankan budaya pesantren sehingga bisa terus bertahan hal ini tidak lain salah satunya dikarenakan adanya peran komunikasi yang cukup signifikan digunakan dalam mengelola manajemen pesantren tersebut baik dituangkan dalam komunikasi lisan/tulisan atau non verbal. Pengulangan pesan berupa aturan-aturan yang sering diingatkan atau nilainilai budaya sering diingatkan secara berulang-ulang kepada santri pada saat mereka belajar dikelas/diluar kelas jelas akan semakin menanamkan sebuah pesan dalam pemikiran seseorang.

Sekali lagi budaya-budaya pesantren yang ada ditiap pontren bisa terjaga alias bertahan tentunya tidak lepas dari peran komunikasi antar pelaku komunikasi (pihak pontren) dengan tujuan memberikan efek komunikasi dalam mempertahankan budaya pontren itu hal ini membentuk terbentuknya sebuah pola komunikasi. Pola komunikasi merupakan rangkaian komunikasi yang melibatkan komunikator selaku pihak yang memberi inisiatif pertama kali dalam berkomunikasi kepada komunikan (penerima pesan) dengan tujuan/efek komunikasi yang bisa jadi dirancang terlebih dulu sehingga efek yang akan dihasilkan harus sinkron dengan pesan komunikasi yang akan disampaikan hal ini untuk mengantisapasi munculnya timbal balik serta hambatan komunikasi yang tidak diinginkan.Untuk menanamkan nilai kesetiaan, peduli, tanggungjawab dalam mempertahankan budaya pontren tidak lepas adanya usaha-usaha komunikasi yang dibangun sehingga membentuk sebuah pola komunikasi yang merupakan ciri khas dari 
pontren itu. Pola komunikasi yang terbentuk adalah gambaran adanya interaksi antara pelaku komunikasi untuk mengkomunikasikan symbol-simbol pesan berupa pesan system budaya sehingga budaya pesantren tetap bertahan.

Apabila dilihat dari teori interaksionisme simbolik jelas ketiga budaya pesantren tersebut bisa bertahan karena memang adanya pertukaran symbol dalam interaksi antara pihak - pihak yang ada didalam pontren sehingga budaya bisa bertahan. Interaksionisme simbolik adalah sebuah pemikiran yang berfokus pada cara-cara manusia membentuk makna dan susunan dalam masyarakat melalui percakapan.Barbara Ballis Lal meringkaskan pemikiran gerakan ini yakni: ${ }^{20}$

- Manusia membuat keputusan dan bertindak sesuai dengan pemahaman subjektif mereka terhadap situasi ketika mereka menemukan diri mereka.

- Kehidupan sosial terdiri dari proses-proses interaksi daripada susunan sehingga terus berubah.

- Manusia memahami pengalaman mereka melalui makna-makna yang ditemukan dalam simbol-simbol dari kelompok utama mereka dan bahasa merupakan bagian penting dalam kehidupan sosial.

- Dunia terbentuk dari objek-objek sosial yang memiliki nama dan makna yang ditentukan secara sosial.

- Tindakan manusia didasarkan pada penafsiran mereka, dimana objek dan tindakan yang berhubungan dalam situasi yang dipertimbangkan dan diartikan.

- Diri seorang merupakan sebuah objek yang signifikan dan layaknya semua objek sosial, dikenalkan melalui interkasi sosial dengan orang lain.

Pontren adalah sebuah sistem yang terdiri dari kumpulan sumber daya manusia dan sumber daya lainnya. Untuk mempertahankan budaya tersebut para komunikator (pimpinan pontren) juga harus dapat berkomunikasi dengan melihat kelompok yang akan diajak berkomunikasi. Apabila dilihat dari hasil temuan yang ada oleh penulis, para pengelola pontren terlihat focus mempertahankan budaya pesantren ini dengan melibatkan para pendidik dan kelompok santri (anak didik) selaku komunikan yakni pihak yang menerima pesan.

${ }^{20}$ Stephen W Littlejohn dan Karen A Foss, Teori Komunikasi, hlm. 231-232. 
Pola Komunikasi dalam Mempertahankan Eksistensi Budaya Pesantren di Pulau Bangka

Dell Hymes seorang antropolog memberi saran bahwa terdapat sembilan hal yang dapat digunakan untuk membandingkan budaya yang berbeda yakni: Pertama, Logat atau pola komunikasi yang dikenali dari anggota kelompok. Kedua, Kelancaran ideal pembicara atau apa yang mendasari seorang pelaku komunikasi patut dicontoh. Ketiga, Komunitas percakapan atau kelompok dan segala batasannya. Keempat, Situasi percakapan atau semua waktu saat komunikasi dianggap tepat dalam komunitas. Kelima, Peristiwa percakapan atau kejadian apa yang dianggap menjadi komunikasi bagi anggota kelompok. Keenam, Speech act atau serangkaian perilaku spesifik yang diambil sebagai sebuah contoh komunikasi dalam sebuah peristiwa percakapan. Ketujuh, Komponen speech act atau apa yang dianggap menjadi elemen dari sebuah tindakan komunikatif. Kedelapan, Aturan bicara dalam komunitas atau tuntunan atau standar dimana perilaku komunikatif diputuskan. Kesembilan, Fungsi bicara dalam komunitas atau komunikasi apa yang diyakini menuntaskan. ${ }^{21}$

Berkaitan dengan hal diatas Dalam mempertahankan budaya diketiga pesantren ini dari sudut komunikasi kita dapat melihat bahwa komunikasi dapat dituangkan dalam komunikasi lisan, tulisan atau non verbal baik yang tertuang dalam situasi formal/informal. Apabila merujuk dari teori Etnografi komunikasi adalah yang merujuk pada pola komunikasi sebuah kelompok ada penerapan komunikasi tertentu yang dilakukan oleh pengelola pontren kepada para santri khusunya untuk mempertahankan system budaya yang ada. Secara teori etnografi komunikasi melihat dari sisi: 1) pola komunikasi yang digunakan oleh sebuah kelompok; 2) mengartikan semua kegiatan komunikasi ini ada untuk kelompok; 3) kapan dan dimana anggota kelompok menggunakan semua kegiatan ini; 4) bagaimana praktik komunikasi menciptakan sebuah komunitas; dan 5) keragaman kode yang digunakan oleh sebuah kelompok. ${ }^{22}$

Apabila merujuk dari sudut etnografi komunikasi diatas dapat dilihat pola komunikasi dalam situasi formal lebih banyak dibungkus oleh event-event formal seperti peringatan hari besar Islam, milad pontren, perkumpulan dalam pelatihan-pelatihan sehingga pada moment itu menjadi ajang untuk menyampaikan pesan komunikasi. Sedangkan dalam situasi informal lebih banyak dituangkan dalam pendekatan secara personal misalkan dalam menasehati, pemberian motivasi. Dan untuk komunikasi tulisan tidak lepas digunakan

${ }^{21}$ Ibid., hlm. 460-461.

${ }^{22}$ Ibid.

Scientia: Jurnal Hasil Penelitian, Vol. 4, No. 1 (2019) | 81 
untuk mensosialisasikan nilai-nilai/budaya-budaya yang ada di pesantren sehingga nilainilaiyang berupa prinsip, ideologi, peraturan maupun kebiassan sehingga akan dipertahankan nilai tersebut. Pesan-pesan dalam komunikasi tulisan dapat dilihat dari majaah dinding, buku profil, aturan-aturan perilaku yang dipajang/ditempel. Secara keseluruhan nilai-nilai budaya ini sama disosialisasikan baik dalam lingkungan dalam pontren, kelas ataupun masyarakat umum, ketiga lapisan ini saling diintegrasikan untuk menguatkan posisi budaya pontren itu sendiri.

Peneliti melihat nilai budaya pesantren ini juga bisa tetap bertahan karena tidak lepas karena adanya nilai-nilai ke Islaman yang dipegang erat sehingga budaya kekerabatan tetap terikat sehingga ada nya kebersamaan, saling tolong-menolong. Hal ini tentunya tidak lepas dari peran pemimpin dalam memberikan pengaruh kepemimpinannya baik kepada bawahan atau anak didik mereka.

Hal lain yang menarik bahwa pimpinan pontren juga sangat memperhatikan arti peran mereka sebagai pemimpin (komunikator) untuk dapat berkomunikasi secara efektif sehingga apa yang mereka sampaikan keapa santri atau bawahan mereka akan diikuti pembicaraannya. Apa yang diperhatikan tidak cukup hanya sebatas isi pesan namun yang dilihat adalah siapa yang menyampaikan. Para pimpinan pontren ini sangat memahami bahwa harus ada konsisten dari pada apa yang diucapkan mereka (komunikasi lisan) harus sesuai dengan perilaku mereka (komunikasi non verbal) sehingga sosok mereka dapat dipercaya. Kejujuran dalam berucap dan berperilaku (seiya sekata) oleh pimpinan tentunya tidak lepas dari ilmu bahwa menjaga ucapan dan tindakan yang konsisten menggambarkan pemahaman sosok pimpinan yang dalam bertindak sesuai ajaran Islam.

Walaupun jika adanya pergantian dalam fase kepemimpinan pontren namun pada dasarnya tiap pimpinan pontren sangat paham arti peran mereka ketika diberikan amanah kepemimpinan oleh Allah swt semata-mata untuk mempertahankan agar nilai keIslaman tetap bertahan. Pemimpin memiliki peran yang kuat dalam memberikan pengaruh (berperan sebagai influencer) karena pada umunya dengan kewibawaan mereka memiliki daya tarik sendiri. Adanya kehebatan persuasive yang dibangun pengelola pontren sehingga para santri mengikuti aturan semakin dapat menguatkan system nilai budaya itu sendiri.Apalagi para santri dididik untuk patuh menjaga adab kepada guru, menghormati guru, maka secara otomatis akan menghargai guru.

Scientia: Jurnal Hasil Penelitian, Vol. 4, No. 1 (2019) | 82 
Pola Komunikasi dalam Mempertahankan Eksistensi Budaya Pesantren di Pulau Bangka

\section{K. Catatan Penutup}

Ada hal yang menarik bagi peneliti yakni ditemukan ada beberapa subsistem yang cenderung memiliki kesamaan antar ketiga pontren ini (Al Islam, Nurul Ihsan, dan Nurul Muhibbin) walaupun untuk subsistem tertentu memilki ciri khas tersendiri dari tiap pontren. Hal ini tentunya tidak lepas adanya benang merah sejarah yang mengikat ketiga pesantren itu. Selain itu, ketiga pontren ini secara bersama berusaha untuk mempertahankan nilai-nilai budaya (prinsip, ide, nilai, ilmu, kebiasaan-kebiasaan) yang sudah ada sejak dulu yang menjadi ciri khas mereka sejak dulu walaupun dalam mempertahankan budaya tersebut membutuhkan proses yang bisa jadi harus dilewatkan dalam situasi yang tidak selalu mudah, menemui kendala.

Namun, di sisi lain ketiga pontren ini juga tidak menutup kemungkinan bersedia menerima jika adanya budaya baru selama budaya-budaya tersebut tidak berseberangan dengan prinsip yang sudah dipegang pontren selama ini. Para pihak pontren khususnya para pimpinan sangat menyadari untuk mempertahankan nilai budaya pontren tidak akan lepas dari komunikasi. Komunikasi adalah ajang sosialisasi untuk memperatahankan segala system budaya yang ada kepada para generasi khususnya para pendidik maupun para santri.

Terakhir peneliti dapat menuliskan beberapa poin penting terkait hal ini yakni:

1. Budaya pontren yang sudah ada diusahakan tetap dipertahankan karena nilai-nilai yang ada didalam sistem pontren itu memiliki ikatan yang kuat dalam membangun pontren itu sendiri sehingga harus tetap dipertahankan.

2. Sosok pimpinan memiliki kekuatan dalam menggerakan pesantren karena pemimpin memiliki posisi yang kuat dalam memberikan pengaruh kepada bawahan maupun santri sehingga sistem budaya tetap bisa bertahan.

3. Pada akhirnya pola komunikasi tetap memiliki peran yang penting dalam mempertahankan system budaya pesantren sehingga eksistensi pontren tetap terjaga. Hal ini tinggal menjadi kebijakan pontren memilih pola komunikasi seperti apa sebagai bentuk dari pemilihan strategi komunikasi dalam mempertahankan system budaya yang ada. 
Yera Yulista

\section{Daftar Pustaka}

Ardianto, Elvinaro. 2010. Metodologi Penelitian untuk Public Relations Kuantitatif dan Kualitatif, Bandung: Simbiosa Rekatama Media.

Cangara, Hafied. 2018. Pengantar Ilmu Komunikasi. Jakarta: PT Raja Grafindo Persada.

Damopolii, Muljono. 2001. Pesantren Modern IMMIM Pencetak Muslim Modern. Jakarta: Rajawali Press.

Effendy, Uchjana, Onong. 2005. Imu Komunikasi (Teori dan Praktek). Bandung: Rosdakarya. Koentjaraningrat.1990. Pengantar Ilmu Antropologi. Jakarta: PT Rineka Cipta.

Littlejohn, W. Stephen dan Foss A. Karen. 2009. Teori Komunikasi, terj. Theories of Human Communication. Jakarta: Penerbit Salemba Humanika.

Deddy Mulyana, Deddy. 2009. Ilmu Komunikasi Suatu Pengantar. Bandung: PT Remaja Rosdakarya.

Riswandi.2009. Ilmu Komunikasi.Cetakan Pertama. Yogyakarta: Graha Ilmu.

Satori, Djam'an dan Aan Komariah.2009. Metodologi Penelitian Kualitatif. Bandung: Alfabeta.

Siradj, Aqiel Sa’id dkk.1999. Pesantren Masa Depan: Wacana Pemberdayaan dan Transformasi Pesantren. Bandung: Pustaka Hidayah.

Soerjono, Soekanto dan Budi Sulistyowati. 2015. Sosiologi Suatu Pengantar, Edisi Revisi. Jakarta: PT Raja Grafindo Persada.

Sulaiman, Rusydi. dkk,. 2012. Diorama Pendidikan Islam. Yogyakarta: Idea Press Yogyakarta.

Vardiansyah, Dani. 2004. Pengantar Ilmu Komunikasi Pendekatan Taksonomi Konseptual. Jakarta: Ghalia Indonesia

\section{Sumber Wawancara:}

- Wawancara dengan Ahmad Hijazi Ajmain (Pimpinan Pontren Al Islam Kemuja)

- Wawancara dengan H.Zainawi (Pimpinan Pontren Nurul Muhibbin)

- Wawancara dengan Ahmad Habib Sinaga, (Plt Pimpinan Pontren Nurul Ihsan Baturusa)

- Wawancara dengan Drs. H. Junaidi Hamdan (Wakil Pimpinan Pontren/Guru Al Islam Kemuja)

- Wawancara dengan Siti Hijir (Ketua Panti/Mengajar di Nurul Ihsan Baturusa)

- Wawancara dengan Khatamar Rasyid (Ketua Yayasan/Guru Nurul Muhibbin)

- Wawancara dengan Fauziyah (Santriwati Pontren Al Islam Kemuja)

- Wawancara dengan Suziyanti (Santriwati Pontren Nurul Ihsan Baturusa)

- Wawancara dengan Muhamad Ma'ruf Al Khai (Santri Pontren Nurul Muhibbin) 